\title{
Actinoalloteichus spitiensis sp. nov., a novel actinobacterium isolated from a cold desert of the Indian Himalayas
}

\author{
A. K. Singla, ${ }^{1}$ S. Mayilraj, ${ }^{1}$ Takuji Kudo, ${ }^{2}$ S. Krishnamurthi, ${ }^{1}$ G. S. $\operatorname{Prasad}^{1}$ \\ and R. M. Vohra ${ }^{1}$ \\ ${ }^{1}$ Biochemical Engineering Research and Process Development Centre (BERPDC) and \\ Microbial Type Culture Collection and Gene Bank (MTCC), Institute of Microbial Technology, \\ Council of Scientific and Industrial Research (CSIR), Sector 39-A, Chandigarh 160 036, India \\ 2Japan Collection of Microorganisms (JCM), RIKEN BioResource Center, Wako, Saitama \\ 351-0198, Japan
}

\begin{abstract}
An actinobacterial strain, RMV-1378 ${ }^{\top}$, isolated from a cold desert of the Indian Himalayas, was subjected to polyphasic taxonomic characterization. The strain formed branching, non-fragmenting vegetative hyphae and did not produce diffusible pigments. Neither aerial mycelium nor spore formation was observed. The $\mathrm{G}+\mathrm{C}$ content of the DNA was $72.0 \mathrm{~mol} \%$. The strain had chemotaxonomic characteristics typical of the genus Actinoalloteichus and was closely related (99.3\% 16S rRNA gene sequence similarity) to Actinoalloteichus cyanogriseus, currently the only Actinoalloteichus species with a validly published name. However, the results of DNA-DNA hybridization experiments showed $51.9 \%$ relatedness with the type strain of $A$. cyanogriseus. On the basis of the above data and the physiological and biochemical distinctiveness of RMV-1378 ${ }^{\top}\left(=\right.$ MTCC $6194^{\top}=J C M 12472^{\top}=$ DSM $\left.44848^{\top}\right)$, this strain should be classified as the type strain of a novel species of Actinoalloteichus, for which the name Actinoalloteichus spitiensis sp. nov. is proposed.
\end{abstract}

The genus Actinoalloteichus was first described by Liu et al. (1984) but the name of the genus was not validly published. Subsequently, Itoh et al. (1987) reported the morphological and chemotaxonomic characteristics of the genus, and its phylogenetic position was reported by Tamura \& Hatano (1998) and Stackebrandt et al. (1997). The genus name was finally validly published by Tamura et al. (2000). At present, this genus accommodates only one species, Actinoalloteichus cyanogriseus. In this paper, we describe the polyphasic characterization of strain RMV $-1378^{\mathrm{T}}$ and propose it as the type strain of a novel species.

Strain RMV $-1378^{\mathrm{T}}$ was isolated from a soil sample collected from the Lahaul-Spiti Valley, a cold desert of the Indian Himalayas, by using a dilution plating technique on actinomycetes isolation agar (sodium caseinate, $0 \cdot 2 \%$; asparagine, $0.01 \%$; sodium propionate, $0.4 \%$; dipotassium phosphate,

Published online ahead of print on 23 September 2005 as DOI 10.1099/ijs.0.63720-0.

The GenBank/EMBL/DDBJ accession number for the 16S rRNA gene sequence of strain RMV $-1378^{\top}$ is $\mathrm{AY} 426714$.

Chemotaxonomic characteristics of strain RMV-1378 ${ }^{\top}$ and the type strain of $A$. cyanogriseus are available in a supplementary table in IJSEM Online.
$0.05 \%$; magnesium sulphate, $0.01 \%$; ferrous sulphate, $0 \cdot 0001 \%$; agar, $1.5 \%$; $\mathrm{pH} 8 \cdot 1$ ) and maintained as glycerol stocks at $-70{ }^{\circ} \mathrm{C}$. The type strain of $A$. cyanogriseus (MTCC $6195^{\mathrm{T}}$ ) was obtained from the Microbial Type Culture Collection, Chandigarh, India.

Cultural, physiological and biochemical characteristics (Table 1) of strain RMV-1378 ${ }^{\mathrm{T}}$ were examined by using standard procedures (Yokota et al., 1993; Gordon et al., 1974). Some tests were re-examined in this study as indicated in Table 1 . To check growth at different $\mathrm{pH}$ values between $8 \cdot 0$ to $11 \cdot 0$, CM broth (yeast extract, $0 \cdot 4 \%$; malt extract, $1.0 \%$; glucose, $0.4 \%$ ) with different $\mathrm{pH}$ values along with a biological buffer system were used (a solution of $\mathrm{Na}_{2} \mathrm{CO}_{3}$, using $25 \%$ as stock, was used for $\mathrm{pH}$ adjustment). Freeze-dried cells for chemotaxonomic analyses were prepared after growth of the strains for 4 days at $30{ }^{\circ} \mathrm{C}$ in shake flasks containing trypticase soy broth. The whole-cell sugars were analysed by using the HPLC method of Mikami \& Ishida (1983) and the diaminopimelic acid isomer was determined as described by Staneck \& Roberts (1974). Phospholipids and menaquinones were extracted and analysed as described by Minnikin et al. (1984). The absence of mycolic acids was confirmed by TLC (Minnikin \& Goodfellow, 1976). The $N$-acyl type of the muramic 
Table 1. Differential characteristics for strain RMV-1378 and the type strain of $A$. cyanogriseus

+ , Positive; -, negative; w, weakly positive.

\begin{tabular}{|c|c|c|}
\hline Characteristic & $\begin{array}{c}\text { Strain } \\
\text { RMV-1378 }^{\mathrm{T}}\end{array}$ & $\begin{array}{l}\text { A. cyanogriseus } \\
\text { MTCC } 6195^{\mathrm{T}}\end{array}$ \\
\hline $\begin{array}{l}\text { Presence of aerial } \\
\text { mycelium and spores }\end{array}$ & - & + \\
\hline \multicolumn{3}{|l|}{ Utilization of: } \\
\hline D-Glucose & - & + \\
\hline Salicin & + & - \\
\hline Sucrose & + & - \\
\hline D-Maltose & - & + \\
\hline D-Xylose & - & + \\
\hline L-Rhamnose & - & + \\
\hline D-Sorbitol & - & + \\
\hline D-Raffinose & + & - \\
\hline Sodium citrate & + & - \\
\hline Sodium succinate & + & - \\
\hline Decomposition of casein & + & $-*$ \\
\hline Growth in $7 \% \mathrm{NaCl}$ & - & + \\
\hline Hydrolysis of starch & + & $\mathrm{W}^{*}$ \\
\hline Pigmentation in ISP-6 & Absent & Black $^{*}$ \\
\hline $\begin{array}{l}\text { Menaquinone MK-9 }\left(\mathrm{H}_{2}\right) \\
\text { content }(\%)\end{array}$ & Absent & $9^{*}$ \\
\hline DNA G $+\mathrm{C}$ content $(\mathrm{mol} \%)$ & $72 \cdot 0$ & $72 \cdot 5^{*}$ \\
\hline
\end{tabular}

${ }^{\star}$ Data from Tamura et al. (2000).

acid in the cell wall was determined by using the method of Uchida \& Aida (1984). Fatty acid methyl ester analysis was performed by using GLC according to the instructions of the Microbial Identification System (MIDI) (Sasser, 1990).

Genomic DNA extraction, PCR-mediated amplification of the $16 \mathrm{~S}$ rRNA gene sequence, sequencing of the PCR products and determination of the phylogenetic position were carried out as described previously (Nakajima et al., 1999). DNA-DNA hybridization was performed by using the membrane filter method (Tourova \& Antonov, 1987) as described by Reddy et al. (2000). The G + C content of the genomic DNA was determined using the HPLC method as described by Tamaoka \& Komagata (1984).

The 16S rRNA gene sequence of strain RMV-1378 ${ }^{\mathrm{T}}$ generated in this work (1476 bases) was aligned, using the CLUSTAL_X program (Thompson et al., 1997), with the $16 \mathrm{~S}$ rRNA gene sequences of closely related strains (retrieved from the GenBank/EMBL/DDBJ databases); the alignment was corrected manually. A sequence-similarity search was done using the BLASTN program of GenBank (Altschul et al., 1997). For the neighbour-joining analysis (Saitou \& Nei, 1987), distances between sequences were calculated using Kimura's two-parameter model (Kimura, 1980). A bootstrap analysis was performed to assess the confidence limits of the branching (Felsenstein, 1985).

Strain RMV $-1378^{\mathrm{T}}$ showed a high level of $16 \mathrm{~S}$ rRNA gene sequence similarity $(99 \cdot 3 \%)$ to the sole member of the genus Actinoalloteichus, A. cyanogriseus (Fig. 1); sequence similarities to all other species (with validly published names) of related genera were below $95 \%$. The DNA-DNA hybridization experiments revealed $51.9 \%$ relatedness (the mean of $50 \cdot 1$ and $53.9 \%$ ) between RMV- $1378^{\mathrm{T}}$ and the type strain of $A$. cyanogriseus, which is well below the $70 \%$ value recommended for the delineation of bacterial species (Wayne et al., 1987). Strain RMV- $1378^{\mathrm{T}}$ exhibited good growth on Streptomyces agar (malt extract, $1.0 \%$; yeast extract, $0.4 \%$; glucose, $0.4 \%$; calcium carbonate, $0 \cdot 2 \%$; agar, $1.2 \%$ ). Neither aerial mycelium nor spore formation was observed on the media tested (ISP media 1, 2, 3, 4, 5, 6, 7 and 9, Streptomyces agar and actinomycetes isolation agar). No soluble pigment was observed on the above media. Greyish colonies developed on all media tested. Detailed phenotypic characteristics are presented in the species description. Strain RMV $-1378^{\mathrm{T}}$ differs substantially from $A$. cyanogriseus in terms of phenotypic characteristics (Table 1). Most of the chemotaxonomic data confirmed that strain RMV- $1378^{\mathrm{T}}$ belongs to the genus Actinoalloteichus (see Supplementary Table S1 available in IJSEM Online). The cell-wall peptidoglycan contained meso-diaminopimelic acid as a diagnostic amino acid. The whole-cell sugars comprised rhamnose, ribose, mannose, galactose and glucose. The acyl type of the

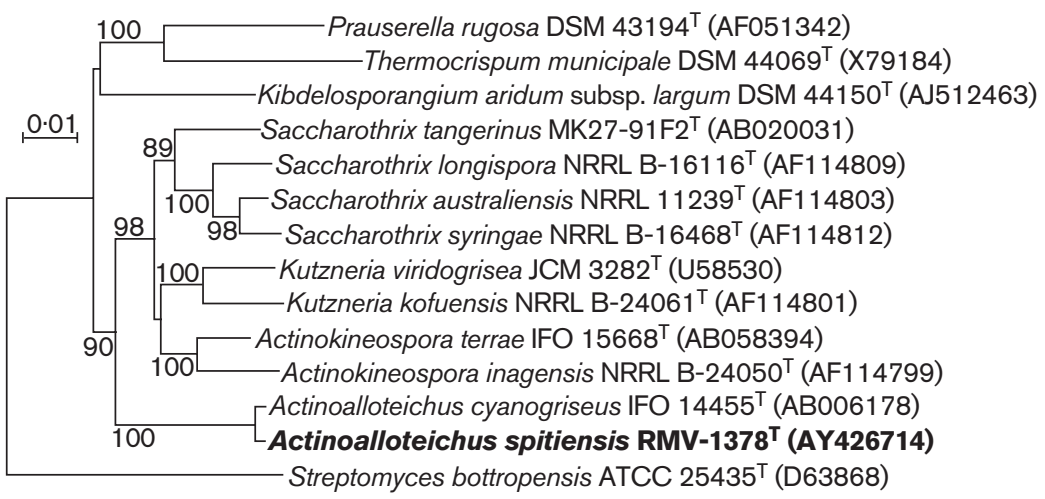

Fig. 1. Neighbour-joining tree, based on $16 S$
rRNA gene (1476 bases) sequences, showing
the phylogenetic relationship between strain
RMV-1378 ${ }^{\top}$ and other close relatives, includ-
ing $A$. cyanogriseus. Streptomyces bottropen-
sis was used as an outgroup. Bootstrap
values (expressed as percentages of 100
replications) greater than $50 \%$ are given at
the nodes. Bar, $1 \%$ sequence variation. 
glycan chain of peptidoglycan was acetyl. The major menaquinone was MK-9 $\left(\mathrm{H}_{4}\right)(82 \%)$; MK-10 $\left(\mathrm{H}_{4}\right)(9 \%)$, MK$8\left(\mathrm{H}_{4}\right)(5 \%)$ and MK-9 $\left(\mathrm{H}_{6}\right)(2 \%)$ were also detected. The predominant cellular fatty acids were iso-branched $\mathrm{C}_{16: 0}$ $(33 \%)$ and $\mathrm{C}_{15: 0}(17 \%)$ fatty acids and anteiso-branched $\mathrm{C}_{15: 0}(7 \%)$ and $\mathrm{C}_{17: 0}(8 \%)$ fatty acids. The phospholipid profile consisted of phosphatidylmonoethylethanolamine, phosphatidylinositol, phosphatidylglycerol, phosphatidylinositolmannosides and diphosphatidylglycerol.

On the basis of a combination of the genotypic and phenotypic data, strain RMV $-1378^{\mathrm{T}}$ is very clearly distinguishable from its phylogenetically closest relative, A. cyanogriseus. Therefore strain RMV-1378 ${ }^{\mathrm{T}}$ represents a novel species of the genus Actinoalloteichus, for which we propose the name Actinoalloteichus spitiensis sp. nov.

\section{Description of Actinoalloteichus spitiensis sp. nov.}

Actinoalloteichus spitiensis (spi.ti.en'sis. N.L. masc. adj. spitiensis pertaining to Spiti Valley, located in the Indian Himalayas, where the type strain was isolated).

Gram-positive, non-acid-fast, aerobic actinobacterium with branching, non-fragmenting vegetative hyphae. No aerial mycelium or spores produced. Positive for utilization of Dmannitol, D-raffinose, sucrose, salicin, sodium citrate and sodium succinate as sole carbon sources. Negative for utilization of D-glucose, D-maltose, myo-inositol, D-fructose, Darabinose, D-xylose, L-rhamnose, D-mannose and D-sorbitol as sole carbon sources. Positive for decomposition of casein and negative for decomposition of urea. No growth occurs on MacConkey agar or in Sabouraud dextrose broth. Positive for hydrolysis of starch and negative for hydrolysis of hippurate and aesculin. Tolerates up to $2 \% \mathrm{NaCl}$ and grows at temperatures between 20 and $37^{\circ} \mathrm{C}$, with an optimum temperature of $25^{\circ} \mathrm{C}$; cannot grow at 15 or $42^{\circ} \mathrm{C}$. Growth occurs at initial $\mathrm{pH}$ values between 6 and 11, the optimum being $\mathrm{pH} 8 \cdot 0$. Chemotaxonomic characteristics correspond to those typical for the genus Actinoalloteichus. Contains major amounts of iso-branched $\mathrm{C}_{16: 0}(33.0 \%)$ and $\mathrm{C}_{15: 0}(17 \cdot 0 \%)$ fatty acids and anteiso-branched $\mathrm{C}_{15: 0}$ $(7 \cdot 0 \%)$ and $\mathrm{C}_{17: 0}(8 \cdot 0 \%)$ fatty acids. Contains a large amount of MK- $9\left(\mathrm{H}_{4}\right)(82 \%)$ and does not contain MK$9\left(\mathrm{H}_{2}\right)$. The $\mathrm{G}+\mathrm{C}$ content of the DNA is $72 \cdot 0 \mathrm{~mol} \%$.

The type strain, RMV $-1378^{\mathrm{T}} \quad\left(=\right.$ MTCC $6194^{\mathrm{T}}=\mathrm{JCM}$ $12472^{\mathrm{T}}=$ DSM $44848^{\mathrm{T}}$ ), was isolated from soil $3600 \mathrm{~m}$ above sea level, at Rangrik Village in Spiti Valley, Himachal Pradesh, India.

\section{Acknowledgements}

We thank Professor Hans G. Trüper for his suggestion on the Latin nomenclature for the novel species. We would like to thank Mr Malkit Singh and Ms Navneet Kaur for their excellent technical assistance. A.K.S. and S.K. are the recipients of CSIR research fellowships. Financial assistance from CSIR and DBT, Government of India, is duly acknowledged. This is IMTECH communication number 63/2004.

\section{References}

Altschul, S. F., Madden, T. L., Schaffer, A. A., Zhang, J., Zhang, Z., Miller, W. \& Lipman, D. J. (1997). Gapped BLAST and PSI-BLAST: a new generation of protein database search programs. Nucleic Acids Res 25, 3389-3402.

Felsenstein, J. (1985). Confidence limits on phylogenies: an approach using the bootstrap. Evolution 39, 783-791.

Gordon, R. E., Barnett, D. A., Handerhan, J. E. \& Pang, C. H.-N. (1974). Nocardia coeliaca, Nocardia autotrophica, and the nocardin strain. Int J Syst Bacteriol 24, 54-63.

Itoh, T., Kudo, T. \& Seino, A. (1987). Chemotaxonomic studies on new genera of actinomycetes proposed in Chinese paper. Actinomycetologica 1, 43-59.

Kimura, M. (1980). A simple method for estimating evolutionary rates of base substitutions through comparative studies of nucleotide sequences. J Mol Evol 16, 111-120.

Liu, Z., Zhang, Y. \& Yan, X. (1984). A new genus of the order Actinomycetales. Acta Microbiol Sin 24, 295-298.

Mikami, H. \& Ishida, Y. (1983). Post-column fluorometric detection of reducing sugars in high-performance liquid chromatography using arginine. Bunseki Kagaku 32, E207-E210.

Minnikin, D. E. \& Goodfellow, M. (1976). Lipid composition in the classification and identification of Nocardia and related taxa. In The Biology of the Nocardiaceae, pp. 160-219. Edited by M. Goodfellow, G. H. Brownell \& J. A. Serrano, London: Academic Press.

Minnikin, D. E., O'Donnell, A. G., Goodfellow, M., Alderson, G., Athaly, M., Schaal, A. \& Parlett, J. H. (1984). An integrated procedure for the extraction of isoprenoid quinones and polar lipids. J Microbiol Methods 2, 233-241.

Nakajima, Y., Kitpreechavanich, V., Suzuki, K. \& Kudo, T. (1999). Microbispora corallina sp. nov., a new species of the genus Microbispora isolated from Thai soil. Int J Syst Bacteriol 49, 1761-1767.

Reddy, G. S. N., Aggarwal, R. K., Matsumoto, G. I. \& Shivaji, S. (2000). Arthrobacter flavus sp. nov., a psychrophilic bacterium isolated from a pond in McMurdo Dry Valley, Antarctica. Int J Syst Evol Microbiol 50, 1553-1561.

Saitou, N. \& Nei, M. (1987). The neighbor-joining method: a new method for reconstructing phylogenetic trees. Mol Biol Evol 4, 406-425.

Sasser, M. (1990). Identification of bacteria by gas chromatography of cellular fatty acids. MIDI Technical Note 101. Newark, DE: MIDI Inc.

Stackebrandt, E., Rainey, F. A. \& Ward-Rainey, N. L. (1997). Proposal for a new hierarchic classification system, Actinobacteria classis nov. Int J Syst Bacteriol 47, 479-491.

Staneck, J. L. \& Roberts, G. D. (1974). Simplified approach to identification of aerobic actinomycetes by thin-layer chromatography. Appl Microbiol 28, 226-231.

Tamaoka, J. \& Komagata, K. (1984). Determination of DNA base composition by reversed-phase high-performance liquid chromatography. FEMS Microbiol Lett 25, 125-128.

Tamura, T. \& Hatano, K. (1998). Phylogenetic analyses on the strains belonging to invalidated genera of the order Actinomycetales. Actinomycetologica 12, 15-28.

Tamura, T., Zhiheng, L., Yamei, Z. \& Hatano, K. (2000). Actinoalloteichus cyanogriseus gen. nov., sp. nov. Int J Syst Evol Microbiol 50, 1435-1440.

Thompson, J. D., Gibson, T. J., Plewniak, F., Jeanmougin, F. \& Higgins, D. G. (1997). The CLUSTAL_X Windows interface: flexible 
strategies for multiple sequence alignment aided by quality analysis tools. Nucleic Acids Res 25, 4876-4882.

Tourova, T. P. \& Antonov, A. S. (1987). Identification of microorganisms by rapid DNA-DNA hybridization. Methods Microbiol 19, 333-355.

Uchida, K. \& Aida, K. (1984). An improved method for the glycolate test for simple identification of the acyl type of bacterial cell walls. J Gen Appl Microbiol 30, 131-134.
Wayne, L. G., Brenner, D. J., Colwell, R. R. \& 9 other authors (1987), International Committee on Systematic Bacteriology. Report of the ad hoc committee on reconciliation of approaches to bacterial systematics. Int J Syst Bacteriol 37, 463-464.

Yokota, A., Tamura, T., Hasegawa, T. \& Huang, L. H. (1993). Catenuloplanes japonicus gen. nov., sp. nov., nom. rev., a new genus of the order Actinomycetales. Int J Syst Bacteriol 43, 805-812. 